\title{
Honorifics in Northern Kurmanji with Reference to English
}

\author{
12Parween Saadi Abdulaziz, ${ }^{2}$ Izzuddin Rajab Mohammad \\ ${ }^{1}$ Department. of English, Salahaddin University, Kurdistan Region-Iraq \\ ${ }^{2}$ Department. of English, Nawroz University, Kurdistan Region-Iraq
}

\begin{abstract}
Honorifics are elements of language that can be represented by both lexical categories like nouns and functional categories like pronouns. They are respect, formality, and distance- related concepts and they have been of major concern to many sociolinguists and pragmatists. The current work is a pragmatic and sociolinguistic approach to honorifics in Northern Kurmanji/ Bahdinan area with reference to English. Data are collected from Waar TV. program "دنكَي گوندى" The Voice of Village. Honorifics are identified and classified into categories; then they are explained. Data analysis shows that Northern Kurmanji does not achieve honorification morphologically, but rather lexically. Thus, it is a non- honorific language. Moreover, not only is the second-person plural pronoun used as an honorific, when addressing a single person, but also the first-person plural pronoun. Sometimes, the core function of honorifics is reversed to show disrespect in the context of irony.
\end{abstract}

KEYWORDS: Honorifics, Politeness, T/V Forms, Address Terms, Kinship Terms.

\section{Introduction}

Honorifics are linguistic forms of politeness that signal respect and social distance. Honorifics are usually conveyed through morphological, lexical and grammatical forms (Matthews, 2007, p. 146). Honorifics have always been of great significance in communication. They provide much information about the person addressed or referred to. They also sooth the situation and serve politeness purposes among the participants in any conversation be it casual or formal.

\subsection{Aims of the Study}

The objective of this research is to provide an academic investigation of honorifics in Northern Kurmanji from a sociolinguistic and a pragmatic perspective.

\subsection{Research Questions}

The following research questions guide the investigation of the use of honorifics in Northern Kurmanji:

- What honorifics do Northern Kurmanji speakers use?

- At what language level does honorification work in Northern Kurmanji?
- What are the factors that affect the use of honorifics in Northern Kurmanji spoken discourse?

\subsection{The Hypotheses}

As preconceptions of the topic of the current study, the following hypotheses are formulated:

- Honorification in Northern Kurmanji is not realized morphologically, but rather lexically.

- It is only the second person plural pronoun that functions as an honorific in Northern Kurmanji Kurdish.

\subsection{Limits of the Study}

The study is limited to the analysis of spoken Northern Kurmanji Kurdish. The data are taken from WAAR TV. program دمنكي كوندى/'dænge 'gondi:/.

\section{Honorifics: Theoretical Background}

\subsection{Definitions}

The definitions of honorifics in this subsection are organized thematically from general to specific. The view of honorifics is expressed in general in honorific languages, in which the morphological criterion is 
decisive, then the honorifics are tackled from a lexical perspective as they occur in non- honorific languages.

Honorifics are special linguistic forms that express deference towards the addressee or referent. They are regarded as an integral part of politeness in language use and they need to be investigated from pragmatic and sociolinguistic perspectives (Shibatani, 2009, p. 381). Honorifics are a type of social deixis that make a connection between social function and linguistic structure (Irvine, 2009, p. 156). Language users are prone to use diverse ways of expressing honorification as potent symbols of politeness and status inherently endowed with social meaning (Agha, 2007, p. 303). The term honorific refers to a conventionalized usage of lexical or grammatical forms to express respect towards others but not the speaker and it is viewed as addresseecontrolled term which is a sub- kind of terms of address (Matthews, 2007, p. 145). In Japanese the prefix o- is attached to a neutral form of a noun, adjective, or verb to constitute a respectful form, as in "o- kerei, meaning "pretty", the respectful form of the unmarked one "kerei" (Trask, 1993, p. 129).

The definitions provided by both Shibatani (2009, p. 381) and Matthews, (2007, p. 145) are restricted as they attribute honorification to other participants and excludes the speaker. This assumption is untenable as the speaker also can express honorification towards him/herself, using the first-person plural pronoun "We". Honorifics can be commonly seen as a trait of oriental languages and can be expressed by diverse appositional expressions for the sake of dignifying and honoring people addressed or referred to (Aliakbari and Toni, 2008, p. 9).

According to Crystal (2003, p. 221), honorifics convey levels of politeness or respect in comparison with the relevant social status of the interlocutors. They are syntactic or morphological distinctions especially in
Japanese. The notion of honorific does not correlate with formality as it can also be found in informal situations. An honorific designates the implication that this is the person referred to. In Japanese, for example, there are two categories of honorifics which are based on a syntactic criterion. In a Japanese sentence, meaning "The professor helped me.", the verb "help" can be marked to indicate respect for the professor, the subject of the sentence; thus, known as subject honorific. On the other hand, in a sentence meaning "He helped the professor.", a different style of markedness is used to show respect for the professor and this is the case of object honorific (Matthews, 2007, p. 146).

Honorifics are not only viewed as politeness markers but they also signify the speaker's dignity and elegance (Ide, 2005, p. 44). The function of honorifics is not to raise the status of the addressee but to acknowledge such a status. Therefore, honorifics do not create new status but are realizations of the existence of two status: the high status of the addressee/ referent/ bystander and the low status of the speaker (Ide, 2009, p. 231).

For Levinson (1983, p. 89) honorifics are socially- deictic expressions that reflect

the social identities of the participants, i.e. their roles and the social relationship between the interlocutors; or between one of them and the entity or the person referred to.

The term honorific is taken in a broader sense by Tehrani and Yeganeh (1999, p. 108) to incorporate not only addressing terms but other formulaic expressions as well like "Would you...?", "May I...?", etc, taking into consideration that English has no complex system of honorifics compared to some Asian languages like Japanese, Hindi, Madurese, etc. A two- pronged approach is a requirement for the achievement of a thorough study of honorifics: "honorifics as grammatical forms" is a concept easy to approach, whereas their 
study in actual context of situation in terms of pragmatics and sociolinguistics needs elaborate investigation.

Agha (1998, p. 151) uses the term honorific in collocation with register and defines honorific registers as discrete elements, formally and stratified systems, functionally.

This definition indicates that honorifics can be seen as frozen elements of language that can be learnt by heart and they are used according to social (and other domains of life) hierarchies.

The use of honorifics also requires the communicative competence notion suggested by Hymes (1966); the notion of saying what, to whom, when, where and how. The appropriate use of honorifics (and many other socially required linguistic expressions) is vital at a later stage of language speakers when they master language in terms of social conventions and culture.

\subsection{Power and Solidarity}

Honorifics are principal in social life to which they are linked by two dimensions, namely: power and solidarity.

\subsubsection{Power}

Power comes under various titles; such as, social power, status, dominance, authority (Spencer- Oatey, 2008, p. 34) and is nonreciprocal at least between two individuals in the sense that the two cannot have power at the same time. Power is based on many factors, like: age, physical strength, sex, wealth, institutionalized role in religion, state, clan, family, army, etc (Brown and Gilman, 1960, p. 255).

Sociolinguistics and pragmatics deal with power as conveying unequal role relations, like, employeremployee, or teacher- student. However, some relations can be seen as controversial as they are viewed differently by some scholars. For example, driver and passenger have unequal relationship in Blum- Kulka et al.'s (2005) view but an equal relationship in Wood and
Koger's (1991) opinion (Cited in Spencer- Oatey, 2008, p. 34).

French and Raven (1959 cited in Spencer- Oatey, 2008, pp. 34 - 35) suggest five kinds of power:

- Reward Power: If a person has control over another's desired positive outcomes; such as, job promotions and bonus payments.

- Coercive Power: If a person has control over another's unwanted negative outcomes; such as, undesirable tasks, demotion, and allocation.

- $\quad$ Expert Power: A speaker has control over the hearer if the former has knowledge or expertise that the latter needs. Yscout (2014, p. 2) uses the term Information Power to convey the same idea.

- Legitimate Power: A speaker is authorized to prescribe or expect some things or tasks from the hearer due to the former's institutionalized rights. In legitimate power, institutional instructions can be acceptable to some extent as speakers are entitled to practice the power. For instance, a teacher is obliged to handle classroom management issues and has the right to comply students to abide his rules, as in "Get into groups of four!" yet "Get me a cup of tea!" is a personal instruction and is less likely acceptable by the addressee (Spencer- Oatey, 2008, p. 38).

- Referent Power: It is a matter of admiration in which one person is fascinated by another; thus, the latter having power over the former.

Two other types of power are added by Yscout (2014, p. 2) :

- Charismatic Power: It is a naturally endowed attribute of individuals that they have the ability of persuasion by instinct.

- Moral Power: A person who is principled and is concerned with ethical issues where his actions match his words is by no means a powerful person (ibid, p2). 
diagrams show superior and inferior relations:

Interpersonal power relies on the role of deixis in representation. Power can be hardly seen as a unitary concept on the sociological literature; rather, it is a notional concept employed for the description of many diverse things. Power can be deemed in association with entitlement whether the credit is to select one's own course of conduct or to shape others' course of conduct (Agha, 2007, pp. 36- 37).

Power shows superiority, hence it the basic element that leads to the use of honorifics.

\subsubsection{Solidarity}

Solidarity is labeled by diverse terminologies, like, distance, familiarity, closeness, social distance, and relational intimacy (Spencer- Oatey, 2008, p. 35). The relationship to be distant or close can be intuitively understood by people. For example, the period of acquaintance plays a significant role; one may regard a stranger distant from him/her, and a childhood friend as close. From another perspective, one may work with some people for many years yet still sees them distant if he dislikes them. Spencer- Oatey (1996 cited in SpencerOatey, 2008, p. 36) summarizes the pragmatic studies that review some overlapping components of solidarity:

- Positive/ negative effect (Baxter 1984)

- Like - mindedness (Brown and Gilman 1960)

- Similarities/ Difference in Society (Brown and Gilman 1960).

- Familiarity (Holmes 1990)

- Frequency of contact (Slugoski and Trudgill 1988)

- Length of Acquaintance (Slugoski and Trudgill 1988)

Power shows a nonreciprocal relation in which there are two parties in interaction, namely, superior and inferior. The social structure attributes individuals with unique power (Brown and Gilman, 1960, p. 256). The following
(A)

\begin{tabular}{|c|c|}
\hline Superior and Solidarity & $\mathrm{T}$ \\
\hline $\begin{array}{c}\text { Equal and Solidarity } \\
\text { ( T ) }\end{array}$ & $\begin{array}{c}\text { Equal and not Solidarity } \\
\text { (V) })\end{array}$ \\
\hline Inferior and Solidarity $\mathrm{T}$ & V Inferior and not Solidarity \\
\hline
\end{tabular}

(B)

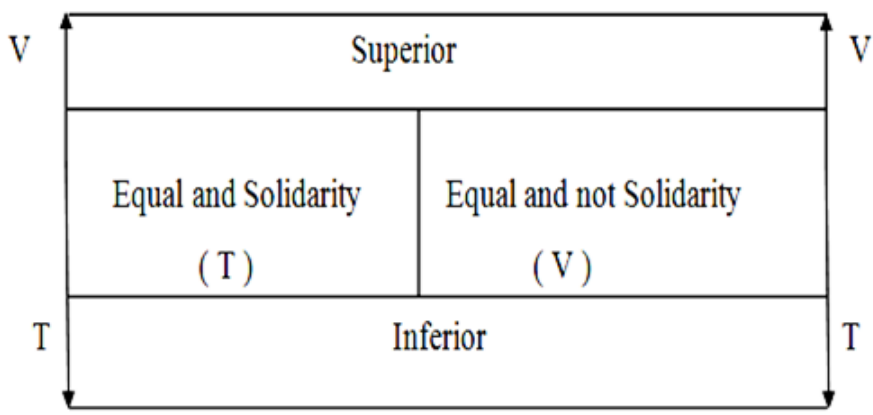

Diagram NO.1: (A) In Equilibrium and (B) Under Tension: The two- Dimensional Semantics (After Brown and Gilman, 1960, p. 259)

The $\mathrm{T} / \mathrm{V}$ forms are the best examples of referent honorifics. These are viewed as social deixis. Power involves asymmetric relations like employer of, stronger than, parent of, nobler than, older than, richer than, while solidarity involves symmetrical relations; such as, attended the same college, practice the same profession and have the same parents. In the case of power, the singular pronoun tu is used by the powerful in addressing the less powerful while the less powerful uses the second person plural pronoun vous in his reply though addressing the single referent. In the case of solidarity, the second person singular pronoun is used interchangeably by the two interlocutors. Conversely, some cases exhibit conflict in which an elder brother can be in a position of both power and solidarity in relation to his younger siblings. Similarly, professions may be 
arranged hierarchically showing degree of dominance thus viewed relatively not completely as a matter of two opposite points + Power and - Power (Palmer, 1981, p. $63)$.

It is to be noted that there is honorific concord between the subject and the finite verb, even when addressing a single referent, $\mathrm{Tu}$ corresponding with elle, and Vous corresponding with ellez as in the following French examples:

- Tu t'appelle comment? (What's your name?) Tu addressing a single referent, meaning you- informal (Second person singular pronoun).

- Vous apellez comment? (What's your name?) Vous addressing a single referent, meaning you- formal (Second person plural pronoun).

The speaker's protection of the other person's face thus can be achieved by using the plural form of "you" and this is accomplished in two ways (Hudson, 2001, p. 124):

- The plural pronoun shows the indirectness strategy by holding the concept of ambiguity. Instead of targeting an individual, a group of people can be the target.

- The person addressed can be regarded as a representative of a group, meaning "you and your group" and this gives them a sense of power.

Furthermore, the choice of the plural pronoun shows generation gap in some cultures like Mijikenda in which the speaker must use the plural pronoun to address his/her uncle even if he is younger (Hudson, 2001, p. 125).

Lyons (1981, p. 319) states that the social and expressive meaning of $\mathrm{T} / \mathrm{V}$ forms stand in sharp contrast with their descriptive meaning; the former has to do with interpersonal meaning while the latter has to do with the ideational meaning. Besides, the interpersonal meaning is socially acquired knowledge which is ultimately culture- specific while the descriptive meaning is linguistically acquired knowledge. Therefore, the social expressive meaning is practical and falls within the domain of social know- how.

\subsection{Classification of Honorifics}

Taking function into account, honorifics are classified into two major classes: Appellative Honorifics and Expressive Honorifics. Appellative Honorifics are those addressed to people according to part of speech and they are of two types: Pronoun Appellative Honorifics and Noun Appellative Honorifics. Noun Appellative Honorifics are sub- divided into: General Appellative Honorifics, Kinship Appellative Honorifics, Subkinship Appellative Honorifics, Rank Appellative Honorifics, Aged Appellative Honorifics, Professional Appellative Honorifics, First Naming Appellative Honorifics, and No Naming Appellative Honorifics. In English Expressive Honorifics at the level of sentence are conveyed by modal auxiliary verbs like "Would you please give me a hand?" "Could you inform me about the meeting date?" Would you mind if I borrow your book?" "Might I make a suggestion?" On the basis of Min et al's typology, the classification of honorifics can be sketched in the following diagram.

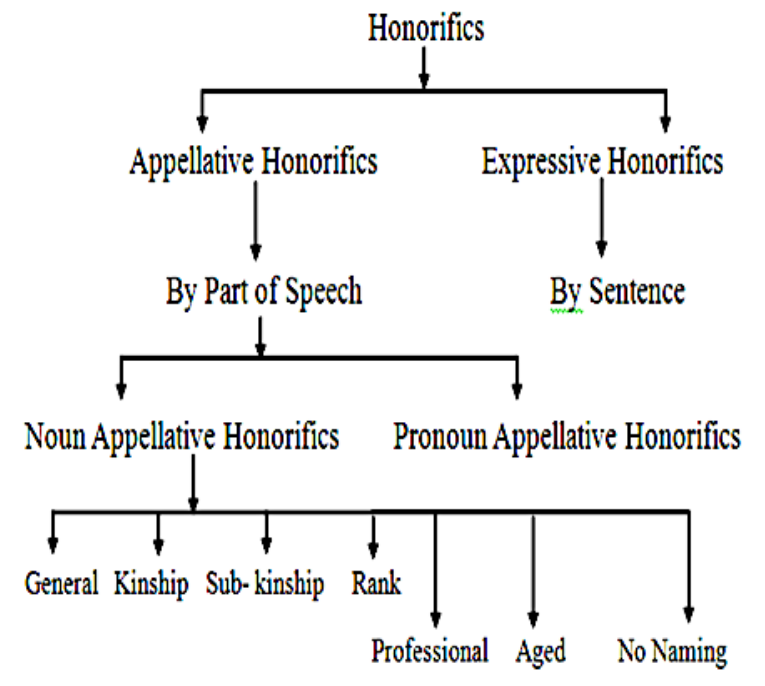

Diagram NO.2: (Min et al's Typology of Honorifics ,2016, p.7, 10)

\subsubsection{General Appellative Honorifics}

One can find such honorifics in general situations. They 
are:

\section{- Sir}

Etymologically speaking, the term was usually used before the name of Baronet or Knight. However, nowadays, it is used by the junior when speaking to the senior as "Will you have anything to drink, sir?" It is also used in formal letters as an introductory device, like Dear Sir, ... (Min et al, 2016, p. 10).

\section{Master}

It is used to refer to a man or boy especially in the United Kingdom (World Heritage Encyclopedia, 2018).

\section{- Madam/ Ma'am}

It counts as a salutation form in a business letter to address a woman, like Dear Madam, ... Shop assistants, servants and waiters use this honorific as in:"How can I serve you, Madam?" It is also used as a professional title or a surname like "Madam President", "Madam Chairman", "Madam Ambassador", "Madam Chairperson" and "Madam John" ... (Min et al, 2016, p. 10).

Both Sir and Ma'am are used by those who perform a service for the one who receives the service, as in "May I take your coat, Ma'am?" (World Heritage Encyclopedia, 2018).

One can claim that the phrase "Madam Chairman" is semantically anomalous as there are two contradicting words conjoining, more explicitly: madam and man. However, the phrase was socially acceptable due to men's dominance of occupations and positions. Conversely, the word 'chairman", along with many others, has been modified to "chairperson" to avoid sex bias, and to cope with the contemporary situation in which women have entered many fields of jobs and positions.

\section{- Lady/ Gentleman}

They address women and men of refined behavior and good manners. They can be used to address audience, like "Good morning ladies and gentlemen!" In the case of Lady, it can be used alone as "You forgot your papers, lady." It can also be used by professional titles, like "Lady President" (Min et al, 2016, p. 10). These honorifics are common in British English more than in American English. Examples are lady secretary, lady champion, gentleman clerk, gentleman author (Mencken, 2009, p. 141).

\section{- Mr. + Last name}

Such a structure is used to address or to refer to a man. It can be used with official and military titles, like "Mr. Senator", "Mr. President" (Min et al, 2016, p. 10). The counterpart is the title "Mistress" which is an old title used to refer to any woman who is the owner of the house or an institution.

\section{- Mrs + Last name}

It refers to a married woman. The use of both Mr. and Mrs. alone implies a vulgar connotation. When an uneducated person uses them, they may be written as mister and misuses (Min et al, 2016, p. 10).

\section{- Miss + Last name}

It indicates an unmarried woman, like Miss John. However, in schools all female teachers are identified with the title Miss regardless of their marital status (Min et al, 2016, p. 10).

\section{- Ms + Last name}

Such a title is useful in the case of not knowing the marital status of the woman (Ibid). The reciprocal use of title and last name can be found in formal exchanges; that is the two interlocutors are of high status in any domain. However, there are nonreciprocal uses of address terms when one is addressed by his/ her first name, but he/ she uses title and last name for addressing. Such a type of exchanges is prevalent among people who are different either in occupational, social, or age status. However, in American culture reciprocity is common even among individuals of different statuses and this is 
not a sign of disrespect but a sense of equality, and humanitarian speaking (Ibid, p. 11).

Putting the original system into place, the social identification of woman was through her relationship to a man, either as a daughter or wife. Some of these forms of address function as social category labels, identifying women's but not men's marital status and attribution (Yule, 2006, p. 222).

When used alone, the M- forms like Mr. seem by themselves rude while Missus is considered uncultivated; therefore, the alternative polite forms are sir and ma'am/ madam (Gramley and Patzold, 1992, pp. 290- 291). Sometimes they are prefixed occupation honorifics, like: Mr. Chairman, Mr. President, Mr. Secretary, etc. These $M$ - forms can have a sense of implicature to count as indirect speech acts. Notably, sir and ma'am do not always function as address forms rather, with rising intonation, they can be equivalent to "Pardon?" to indicate that the speaker has not heard or understood the addressee. Similarly, "Yes, ma'am" is correspondent to "You're welcome" (Ibid, p. 295).

\section{- $\quad$ Mx + Last Name}

This title was introduced in 1977, but it is now taking its way to be popular. This is a gender- neutral honorific used by those who do not want their sex to be identified. The term is becoming more in style in the United Kingdom especially in official documents like driver's licenses and financial documents like in Royal Bank of Scotland. The title of Mx. can also be used as reference to non- binary people; however, this is a restricted term since it is something personal and private. In this case, it cannot be used as an honorific but as an embarrassing title that most people may avoid (Merriam Webster Dictionary, 2018, vs. Mx).

\subsubsection{Kinship Appellative Honorifics}

Kinship is a universal phenomenon that exists in all communities but it differs systematically from one society to another. Human beings exhibit relationships via marriage and blood ties. Taking the componential analysis into consideration, the kinship system can be decomposed into features like [Parent], [Offspring], [Sibling], [Spouse], [Male], and [Female] (Kreidler, 1998, p. 90). The kinship terms were widely used as terms of address compared for the time being. Father, mother, grandfather and grandmother are normally used alone while uncle and aunt can be used alone and also accompanied by the first name of the person concerned though they were previously followed by the last name. These terms are not used in present except in drama. It is to be noted that not all kinship terms can be used vocatively; for example, in- laws and steps they are seldom used for addressing but are used as bystander honorifics (Min et al, 2016, pp. 10).

\subsubsection{Sub- kinship Appellative Honorifics}

Kinship terms are not only used in the case of the existence of blood ties, but they are also employed when there is no such a familial relationship. The terms are originally family expressions, but their meanings are extended to address nonrelatives as well. The kin terms, brother and sister, for example, are common in the field of Catholic group, religion, and professional society. Parent's close friends are usually referred to as Auntie or Uncle. Uncle Sam is the nickname to refer to American Government (Min et al, 2016, p. 11).

\subsubsection{Rank Appellative Honorifics}

One can seldom find rank honorifics with first name and full name in English conversations. Thus, Manager John, Bureau Director John, Principal John are not found in daily interactions. However, such honorifics are used in some provinces of Style, i.e. the domains of discourse like Government Official Ranks such as Governor John, Mayor John, Senator John, Congressman John, Senator John, etc. Besides government ranks, there are also Military Ranks and Religious Ranks like Admiral John, 
Captain John, Colonel John, Father White, and Bishop Gray (Min et al, 2016, pp. 11).

\subsubsection{Aged Appellative Honorifics}

The word "old" is usually avoided to be mentioned as it has a negative connotation indicating uselessness, worthlessness or something to be thrown away. The elderly people are almost always not pleased to be reminded of their old age. Therefore, some mitigated expressions are used to reduce the force of this notion; they are usually referred to as elderly people, senior citizens, aged, veteran, and advanced in age. Almost in all cultures, spanking or reprimanding a child is inevitable when they call the elderly by their first names (Min et al, 2016, p. 11).

\subsubsection{Professional Appellative Honorifics}

Honorifics are sometimes professions- based, such as; Nurse, Doctor, Judge, Professor, etc. Doctor is used to refer to people who have qualifications in the medical profession and those who have got a $\mathrm{PhD}$ certificate in any academic domain. Such honorifics can be used alone or before a person's surname. Boy, Waiter, Usher, and Conductor are other professional appellative forms but not honorifics (Min et al, 2016, p. 11)

\subsubsection{No Naming}

Address terms are usually neglected among close friends, relatives, and strangers (Min et al, 2016, p. 12). However, although honorifics are not used but the level of politeness is expressed in the structure of the sentence thus making use of Ide's notions of volition and discernment. Consequently, in an utterance like "Quit nagging me, will you?" can be used interchangeably between close friends, also, the utterance "Would you mind if I had a look at the newspaper you are reading? can be addressed to an airline passenger in the adjacent seat (Min et al, 2016, p. 12).

It is worth noting that in most cultures there are at least two types of names: one for the identification of people as unique individuals and the other for addressing. The former is known as a given name, like Jack which is applied to a junior relative, while the other is known as a role- based name, like Mum which is applied to a senior relative (Hudson, 2001, p. 126).

Thus, the two types are related to identify two contexts of situation: the first is formal while the other is informal.

\section{Honorifics in Northern Kurmanji}

\subsection{Methodology}

This sub-section is concerned with the procedures and instruments employed to collect and analyze data. The data are taken from WAAR TV. program دمنكي كوندى/ 'dænge 'gondi: / The Voice of Village broadcast within the time span of January 1st, 2019 to March 31 $1^{\text {st }}$ 2019. In this TV program the correspondent indulges in people's life in villages; he introduces many aspects of the way people live and interact with each other to the audience. Twelve episodes are taken as data and the following villages are visited by the correspondent and the staff:

- كوندئ بكركرين The Bargire Village /'gonde bærgi're/

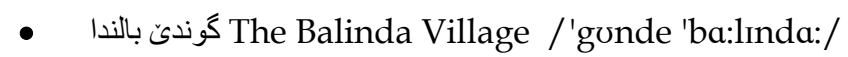

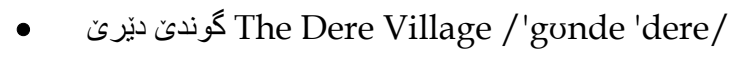

- كَوندئ بوزأ The Boza Village /'gonde 'bo:za:/

- كوندئ دوديا سارىى The Dodya Sary Village /'gonde 'du:drja: 'særi:/

- كوندئ سايد زارى 'za:ri:/

- كوندئ

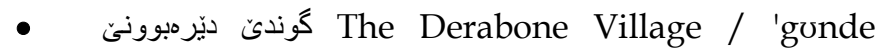
deræ'bu:ne/

- كوندئ كفر ا ائيكيّي The Kifra Eke Village / 'gonde kif'ra: 'Peke/

- كوندئ بانهسووريى The Banesoore Village / 'gonde ba:næ'so:re/

- كوندئ خيزاثا The Khizava Village / 'gonde 'Xi:za:va:/

- كوندئ هدربور The Harbo Village /'gonde hær'bu:/

As for research ethics, the permission is officially taken 
from WAAR TV. (See Appendixes) .

These letters of research ethics are written in the Kurdish language; they are translated into English and stamped by the accredited translator from Duhok Court, Mr. Hakar Hazim Ameen, MA. in Translation.

\subsection{Data Analysis}

The study basically employs Min et al's (2016) model of honorifics with some modifications. (See 2.3) The honorifics of no naming and expressive honorifics shown by the structure of the sentence are excluded. In our opinion, these are functions of modal verbs and speech acts rather than honorifics.

This subsection analyzes honorifics in Northern Kurmanji/ Bahdinan area. The honorifics are identified and classified into categories. Moreover, their frequency in the program is demonstrated in graphs. These honorifics are transcribed into International Phonetic Alphabet. They are also translated into English, and their syntactic categories are identified. Any further explanation necessary is provided.

\subsubsection{General Appellative Honorifics}

i. هيّزْا /he'za:/

Dictionary Meaning: Respectable

Syntactic Category: Adjective, Noun

Type of Honorific: General Appellative Honorific

This is an official term used to refer to highly respectable people in the community whether social or institutional. It can be used in both spoken and written discourse alike.

ii. جواميّر / جيّر/dzza:mer'wa:mer /

Dictionary Meaning: A nice guy

Syntactic Category: Noun, Adjectival

Type of Honorific: General Appellative Honorific

The honorific has two phonological forms as sociolinguistic variations, namely: جاميّر /'dza:mer/ and / جواميّر dzı'wa:mer/. This honorific is solely used for males, it is never used for females; however, sometimes it may be used when women are incorporated as well in the case of pluralization; for example, the utterance خيّز انهكا جاميّره / Xe'za:næka: 'dza:meræ/ (It is a nice family) describes both male and female members.

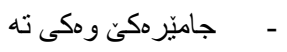

1/dza:meræke wæ'ki: 'tæ/ (A nice guy like you)

$$
\text { - مَوندمكي جاميّر و خوهش مروف }
$$

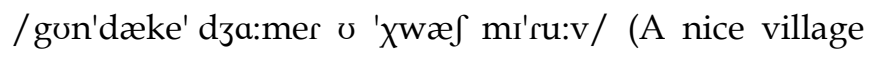
and good people)

There is personification: the village is described as nice, but actually the people are nice. This term may convey the opposite of its meaning in some specified contexts when it is used to refer to an un-wanted person without mentioning his name, as in: جاميّرى نانئينه نافَّى وى / 'na:ve wi: 'dza:meri: næ' 'i:næ/ (Don't mention the name of that nice guy.)

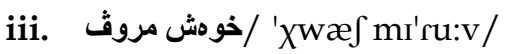

Dictionary Meaning: Good people

Syntactic Category: Noun, Adjectival

Type of Honorific: General Appellative Honorific

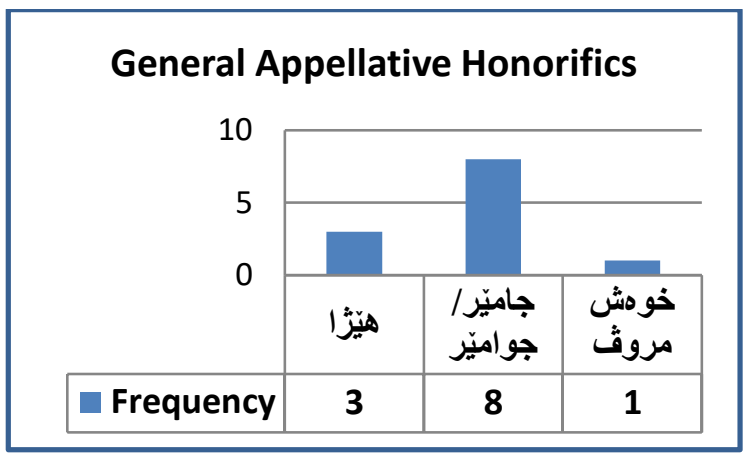

(Graph NO.1: Frequency of General Appellative Honorifics)

\subsubsection{Aged Appellative Honorifics}

i. ملن/mæzin/

Dictionary Meaning: Elder

Syntactic Category: Adjective, Noun

Type of Honorific: General Appellative Honorific

This is an honorific from a social perspective as it does not only refer to the individual as old in age or describing the shape as big but it is also used beyond the dictionary meaning to indicate a well experienced person and the one who has a high social status in the 
society, probably a leading one. Although it can designate both males and females, it is primarily for males. Consider the following utterances:

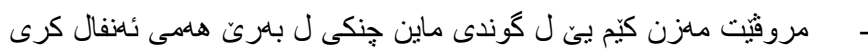
بوون.

/ mi'ru:vet 'mæzın 'kem je g gun'de mæ tfin'ki: 1 bæ're hæ'mi: ?ænfa:l kı'ri: 'bu:n/

(The elder are less in the village because they were the victims of Anfal campaign. )

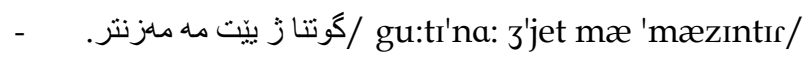

(The saying of those elder than us)

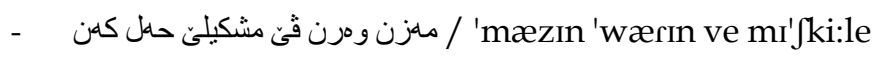
'hælkæn/

(Elderlies, come and solve this problem!)

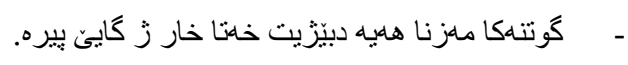

/'gutınæ'ka: mæzı'na: 'hæjæ dbe'zi:t Xæ'ta: 'Xa:؟ 3ı 'ga:je 'pi:ræ/

(A proverb says: deficiencies are the faults of the elders.) كoth the terms مدزيي / 'mæzin/, meaning "big" and ي بير / 'ga:je 'pi:r/, meaning "old bull" refer to the elder; however, the first is an honorific to give the individual a high elevated rank in society, the second is a belittling one as it shows the ill performance of the one who is of a high rank in society in his duties. Even when mentioned out of context, the phrase / 'ga:je 'pi:r/, meaning "old bull" has a negative connotation as it is a common expression used in the Kurdish community.

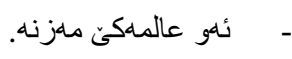

/ 'eu 'Ga:Irmæke 'mæzınæ/ (He is a great scholar.)

The honorific مدزن / mæzin/ does not refer to age, but to the person who has a high knowledgeable status and such an expression is only used with males because it refers to religious people, namely men. It is to be noted that the expression بناقي خودى مدزن و دلوثان / bI'na:ve 'XUde 'mæzınu: dilu:'va:n/ (In the name of Allah, the Gracious, the Merciful) is used at the beginning of any work human beings do as an indication of getting blessings. ii. ري سبيى/" ri:spi:/

Dictionary Meaning: Greybeard

Syntactic Category: Noun, Adjectival

Type of Honorific: Rank Appellative Honorific

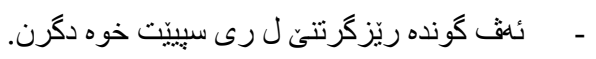

/'Pæf gon'dæ 'rezgIrtıne lı 'ri:sprjet 'Xwæ dgI'ri:t/

(This village respects its greybeards.)

Notice that the phrase is polysemous in the sense that it may refer to an elderly (with grey beard ره سيى /'rIh 'spi:/) that has a significant role and respect in the community; he helps the other members of the community and people consult him for his experience to solve social issues. It may also designate other people (irrespective of their age) who do virtues to others.

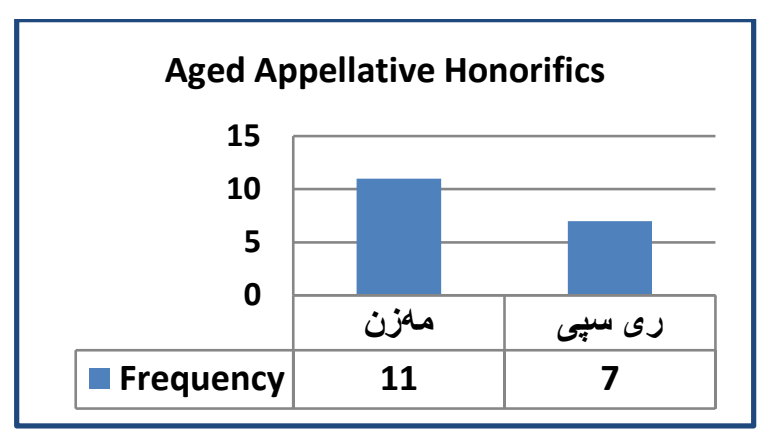

(Graph NO.2: Frequency of Aged Appellative Honorifics)

\subsubsection{Rank Appellative Honorifics}

i. أناغا /'Pa:ya: /

Dictionary Meaning: Agha - A tribal chieftain or village head

Syntactic Category: Noun, Adjective

Type of Honorific: General Appellative Honorific ف / fær'ha:n '?a:ya: / is a prominent figure in a clan. The name also has political and social implications like the leader of a group of peshmarga. The agha is usually the main judge, arbitrator and the military leader of his armed tribesmen.

ii. مختار / mu X'ta:r/

Dictionary Meaning: Mayor / village chief

Syntactic Category: Noun, Adjectival

Type of Honorific: General Appellative Honorific 
This honorific is specific to villages where this person is responsible for the social affairs of village people who are usually relatives. This is the case in rural areas; however, in urban areas the situation is different as there is a mukhtar for each quarter or neighborhood.

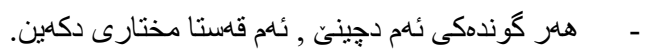

/ 'hær 'gondæki: 'Pæm d'tfi:ne '?æm qæs'ta: mox'ta:ri: d'kein / (Any village we visit, we go to the mayor.)

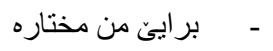

/bi'ra:je' min moX'ta:ræ/ (My brother is a mayor.)

In this utterance, the term مختار /moX'ta:r/ is a bystander honorific, referring to the one who is not involved in conversation, i.e. he is absent and when going further beyond the literal meaning, it may be interpreted as an honorific for the speaker towards himself to say he is from a high rank because he is the brother of the mayor.

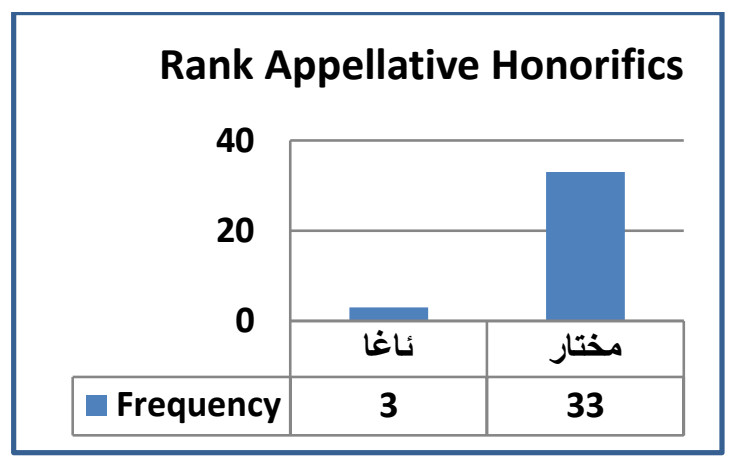

(Graph NO.3: Frequency of Rank Appellative Honorifics)

\subsubsection{Religious Appellative Honorifics}

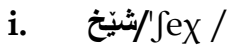

Dictionary Meaning: Sheikh- A man of a high religious rank

\section{Syntactic Category: Noun, Adjectival}

Type of Honorific: Religious Appellative Honorific

This is an honorific that can be used in both religions: Islam and Yazidi. A Sheikh also has a high social status as he is in charge of some social tasks. For the sake of achieving more respect, this honorific usually جهنابيّ شيَّى /dzæ'na:be 'fexi:/ (His Excellency the Sheikh).

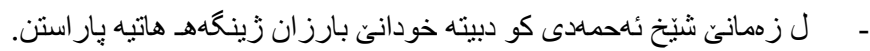

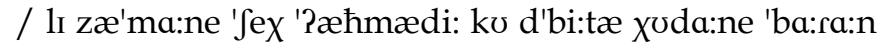
3i:n'gæh 'ha:trjæ 'pa:ra:stın/

(At the time of Sheikh Ahmed, the chieftain of Barzan area, the environment was protected.)

ii. $y \alpha-/ m æ ' l a: /$

Dictionary Meaning: Mulla- an educated religious man Syntactic Category: Noun, adjectival

Type of Honorific: Religious Appellative Honorific This can be a rank appellative honorific with regard to religious figures. A It is a professional honorific for the person who leads prayers in mosques, delivers religious sermons, and performs religious ceremonies. The person who leads prayers is called إمام / Pi:'ma:m/, a loan word from Arabic. This term is also used collocationally with the name of the political figure مهلا مصطفى بارزانى / mæ'la: mistæ'fa: 'ba:rza:ni:/.

\section{iii. / حهجى 'hæ'dzi:/}

(a Muslim who has been to Mecca as a pilgrim / male) ə iv. حهبيا Һæd3'jə /

(a Muslim who has been to Mecca as a pilgrim / female) Syntactic Category: Noun, Adjectival

Type of Honorific: Religious Appellative Honorific

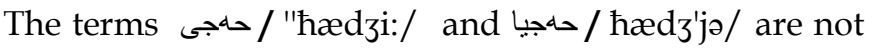
only restricted to the ones who performed the religious ceremonies of Haj, but they are also used to address and refer to old men and women whether they are family members or strangers. In such a case it is only used to show respect to the people addressed. These honorifics can be used alone and with names; however, the term حهج / 'hæ'dzi:/ is used for female when it is accompanied by name, like حهجى علدلا / hædzi: 'Sædla:/.

v. رحمنتى / ræhmæ'ti:/

Dictionary Meaning: The late

Syntactic Category: Noun

Type of Honorific: Religious Appellative Honorific

vi. خودئ زَئ رازى Xode ze 'ra:zi:/

Dictionary Meaning: May Allah be pleased with him. 
Syntactic Category: Sentence: Subject + Prepositional Phrase + Adjectival.

Type of Honorific: Religious Appellative Honorific

This honorific can be manipulated syntactically to have different pragmatic meanings, though the semantic meaning is the same. For example, خودي ذَّ رازى / 'Xode ze 'ra:zi:/ is an honorific that has the implied meaning of praying for a person who passed away, meaning " May Allah be pleased with him." Conversely, the same phrase is used to address a person directly to convey the speech act of complaining, as in خودئ زتنه رازى Xude ztæ 'ra:zi:/, having the meaning opposite of respect. Thus, one can show that the use of a pronoun in this phrase is a decisive factor to determine the phrase as an honorific, when referring to a dead person, or a belittling expression, when addressing a person involved in the interaction, he/she is alive and kicking.

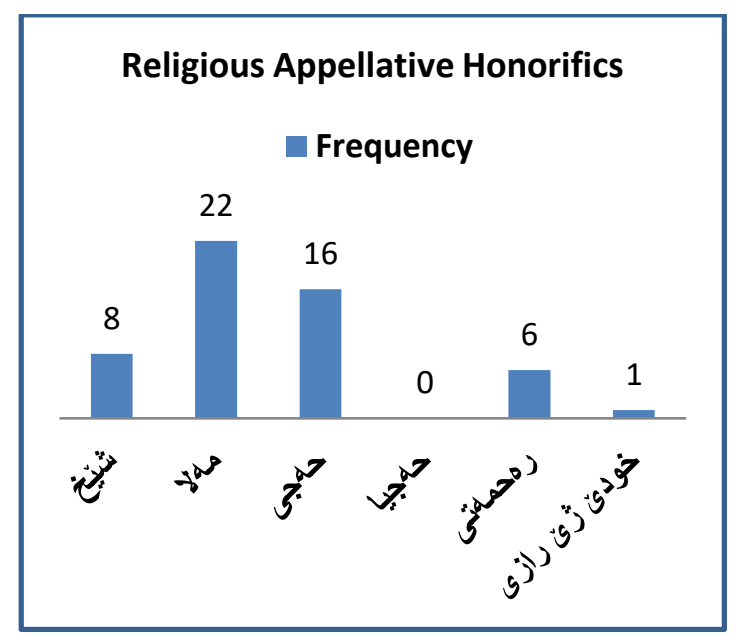

(Graph NO.4: Frequency of Religious Appellative Honorifics)

\subsubsection{Professional Appellative Honorifics}

i. ماموستا / 'ma:musta:/

Dictionary Meaning: Teacher

Syntactic Category: Noun

Type of Honorific: Professional Appellative Honorific

It can be an occupation honorific for both males and females, meaning "teacher" and also a general honorific, belonging to "M- forms". However, sometimes the term is specified according to the institution as in ماموستايئ كوليئ
/ ma:mus'ta:je ku'lije/, (College Teacher) and زانكوييّ / ماموستايئ/ ماموستايا "University Teacher".

ii. معلم/mo'Sælım/

Dictionary Meaning: Teacher of Primary School

Syntactic Category: Noun

Type of Honorific: Professional Appellative Honorific

This is a borrowed honorific form Arabic, written according to the Kurdish orthography. It is used only for males.

iii. استاذ / Pus'ta:ð/

Dictionary Meaning: University Teacher

\section{Syntactic Category: Noun}

Type of Honorific: Professional Appellative Honorific Because the sound / $\partial /$ does not occur in the Kurdish language, uneducated people may pronounce it as استاز / Pus'ta:z/, changing/ð/ into /z/.

iv. سمليدا/sei'da:/

\section{Dictionary Meaning: Teacher}

\section{Syntactic Category: Noun}

Type of Honorific: Professional Appellative Honorific

This honorific is used to address and refer to those who teach in an educational institution, but it may be used to refer to any other person from a high rank. Thus, it can be an occupational - bound honorific and also a general honorific, indicating an intersection between the types sometimes, merely meaning "Mr."

v. موهنديس/mo'hændis/

Dictionary Meaning: Engineer

Syntactic Category: Noun

Type of Honorific: Professional Appellative Honorific This is a borrowed honorific form Arabic written according to the Kurdish orthography. It is used only for males. As for ئندازيار / Pæn'da:zja:r/, it is purely Kurdish and is common nowadays especially in mass media.

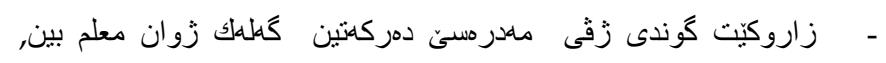

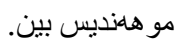


/ 'za:ru:ket 'gondi: zve 'mædræse 'dærkæti:n 'gælæk

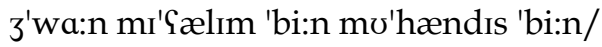

(Children of this village studied in this school and became primary school teachers and engineers.)

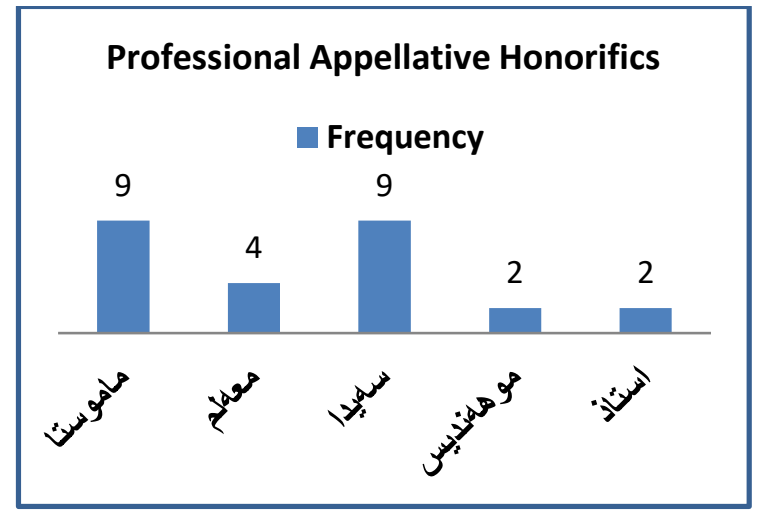

(Graph NO.5: Frequency of Professional Appellative Honorifics)

\section{Conclusions}

The study has come up with the following conclusions:

- There are many lexical honorifics in Northern Kurmanji, but the language has no honorific affixes. Accordingly, Northern Kurmanji can be classified as a non- honorific language. This verifies the first hypothesis which states that honorification in Northern Kurmanji is not realized morphologically, but rather lexically.

- It is not only the second person plural pronoun that can convey the meaning of honorification; the firstperson plural pronoun is also used for the same social function. This refutes the second hypothesis.

- Honorifics are not used randomly in Northern Kurmanji; some honorifics are court- bound expressions and others are used to address and refer to those of a high social status, and even among commoners. To be brief, there are no restrictions to the use of honorifics. Social dynamics of royal courts, aristocracies, and hierarchical societies are not prerequisites to trigger the use of honorifics; hence, they can also be found in day- to- day interactions or for the sake of denoting respect and distance.
- The core meaning of honorification is politeness and respect, yet the opposite meaning of underestimation and disrespect can be employed when honorifics are used ironically.

- Because the Kurdish community focuses on social stratification, the social variables, like age, sex, occupation, religion, politics, etc. are also the predetermined factors in the use of honorifics.

\section{References}

1. Agha, A. 1998. Stereotypes and registers of honorific language. Language in Society. Available [5th August 2018] at

https://www.researchgate.net/publication/248686592_S tereotypes_and_Registers_of_Honorific_Language

2. Agha, A. 2007. Language and social relations. Cambridge: Cambridge University Press.

3. Aliakbari, M. and Toni, A. 2008. The realization of address terms in modern Persian in Iran: A sociolinguistic study. Available [10th August 2018] https://www.linguistik-online.de/35-08/aliakbari.pdf.

4. Blum- Kulka, S. (2005): “The Metapragmatics of Politeness in Israeli Society". In: Watts, R., Ide, S. \& Ehlich, K. (eds.), Politeness in Language: Studies in its History, Theory and Practice, Berlin: Mouton deGruyter, p. 255- 280.

5. Brown, P. and Levinson, S. 1987. Universals of language use. Cambridge: Cambridge University Press.

6. Crystal, D. 2003. A dictionary of linguistics and phonetics 5th ed. Oxford: Blackwell Publishing.

7. Gramley, S. and Patzold, K. 1992. A survey of modern English. London: Routledge

8. Hudson, R. 2001. Sociolinguistics 2nd ed. Cambridge: Cambridge University press

9. Hymes, D. 1966. "Two types of linguistic relativity". In: Bright W. (ed.), Sociolinguistics. The Hague: Mouton, pp. 114- 158.

10. Ide, S. 2005. "How and why honorifics can signify dignity and elegance: The indexicality and reflexivity of linguistic rituals". In: Lakoff, R. and Ide, S. (eds.). Broadening the horizon of linguistic politeness. Amsterdam: John Benjamins Publishing Company, pp. 45- 64.

11. Ide, S. 2009. "Formal forms and discernment: two neglected aspects of universals of linguistic politeness ". In: Piller, I. (ed.), Multilingual journal of cross- cultural and interlanguage communication VOL 8, Issue 2-3. Berlin: Mouton de Gruyter, pp. 223- 248.

12. Irvine, J. 2009. . “Honorifics”. In: Senft, G., Östman, J. and Verschueren, J. (eds.). Culture and language use. Amsterdam: John Benjamins Publishing Company, pp. 156- 172.

13. Kreidler, Ch. 1998. Introducing English semantics. London: 
Routledge, Francis and Taylor Group.

14. Levinson, S. 1983. Pragmatics. Cambridge: Cambridge University Press.

15. Lyons, 1981. Language and linguistics: An introduction. Cambridge: Cambridge University Press.

16. Matthews, P. 2007. The concise Oxford dictionary of linguistics. Oxford: Oxford University Press.

17. Mencken, H. 2009. The American language: A preliminary enquiry into the development of English in the United States. New York: Cosmo Classics.

18. Min, H., Meng, M. And Ying, H. 2016. A cross- cultural analysis of honorifics in modern Chinese and American English. Cross-cultural Communication Journal VOL. 12, NO. 11, pp. 7- 15. Canadian Academy of Oriental and Occidental Culture. Available [12 ${ }^{\text {th }} \quad$ August 2018 at https://www.cscanada.net/index.php/ccc/article/view File/9062/9891

19. Shibatani, M. 2001. "Honorifics". In: Mesthrie, R. and Asher, R. (eds.), Concise encyclopedia of sociolinguistics, Amsterdam: Elsevier, pp. 552- 559.

20. Spencer- Oatey, H. 2008. Culturally speaking: culture, communication and politeness theory. London: Continuum International Publishing Group.

21. Tehrani, T. and Yeganeh, A. 1999. A dictionary of discourse analysis. Tehran: Reahmana.

22. Trask, R. 1993. A dictionary of grammatical terms in linguistics. London: Routledge.

23. Yscout. 2014. Eight Types of Leadership Power. Available [1 ${ }^{\text {st }}$ September 2018]

at https://yscouts.com/executive/types-of- leadershippower/

24. Yule, G. 2006. The study of language 3rd ed. Cambridge: Cambridge University Press.

25. English Honorifics. 2018. World heritage encyclopedia. Available [4 $\quad$ September 2018] at http://self.gutenberg.org/articles/eng/english_honorifi CS.

26. Caste. 2018 Merriam Webster Dictionary. Available [5th September 2018] at https://www.merriamwebster.com/dictionary/caste 